\title{
Correlation between Emotional Intelligence and Transformational Leadership Behaviour
}

\author{
Humaira Naznin ${ }^{1}$ \\ ${ }^{1}$ Lecturer, Dept. of Management \& HRM, American International University-Bangladesh
}

\begin{abstract}
The purpose of this article is to analyse how emotional intelligence and transformational leadership are interrelated. Transformational leadership and emotional intelligence are defined and critically discussed exploring the components of theories of leadership theories. Following theoretical perspective the paper constructs the coherent linkage between the competencies of transformational leadership and emotional intelligence. Emotional intelligence and transformational leadership behavior are found interconnected and complementary.
\end{abstract}

Keywords: Emotional Intelligence, Transformational leadership

\section{Introduction}

Continued research on Transformational leadership and Emotional intelligence shows many social scholars' growing interest in the study of emotional intelligence and its relationship to transformational leadership. Yet it is indeed a mammoth task to define an apparent relationship between emotional intelligence and transformational leadership. Transformational leaders are in this respect more successful compared to those of transactional. Emotional intelligence is a prerequisite for a successful transformational leader. Emotionally intelligent leaders are thought to be happier in the workplace and more committed to their organisation (Abraham, 2000), achieve greater success (Miller, 1999), perform better in the workplace (Goleman, 1998; Watkin, 2000), take advantage of and use positive emotions to envision major improvements in organisational functioning (George, 2000), and use emotions to improve their decision making and instil a sense of enthusiasm, trust and co-operation in other employees through interpersonal relationships (George, 2000). Therefore, an effective management of emotional intelligence is useful for transformational leaders to be able to manage positive and negative emotions in themselves and subordinates.

\section{What is Transformational Leadership?}

Transformational leadership (TL) has become a widely researched paradigm in the field of leadership. Bass (1998) and Avolio, (1999 cited in Harms \& Crede, 2010, p. 6) consider TL "a full range leadership theory" which allows a leader to learn how to evoke followers' emotion, to drive their motivation, to develop them as individual and to achieve goals. TL maintains an "emotion-laden relationship" (Kuper \& Weibler, 2005, pp. 369-370) where a leader transforms the followers to a higher level of motivation, potential, and performance; moves them towards a higher standard of idealised goals, values, and morality; drives them to get engaged with consciousness and need; and finally stimulates the followers to "transcend their own self-interest" by creating a strong emotional bond with the followers (Northouse, 2007). It can be viewed as a two way process where both the leaders and the followers are internally and emotionally engaged with each other and are strongly concerned with "collective good" (Northouse, 2007) without any kind of material exchange or reward.

\section{Dimensions of Transformational Leadership}

Bass (1998) identified four dimensions of TL: idealised influence, inspirational motivation, intellectual stimulation, and individualised consideration. According to Harms \& Crede (2010), idealised influence is the socialised charisma of leaders which determines their high moral standards and values, high-order belief and ideals, and strong visionary power. Because of this powerful charisma the leaders act as a role model to the followers and transfer their ideals and values to the followers.

Inspirational motivation deals with the leaders' ability to inspire and make appeal to followers by setting challenging goals and giving emotional support and optimistic communication to attain the desired goal (Harms \& Crede, 2010). Thus, inspirational motivation is an exceptional quality of leaders to act as a transformer in inspiring his or her followers through motivation and shared vision.

The leader's behavioural engagement with the followers to challenge their (followers) own beliefs and assumption, think creatively, act proactively, take risks and participate intellectually can be described as intellectual stimulation. By stimulating intellectually the leader aims to extend their followers' efforts in terms of innovation and creativity (Wang \& Huang, 2009). Hence, suggesting alternative problem solutions the 
transformational leader turns the negative feelings, for instance frustration and helplessness, to more positive and constructive feelings, such as challenge.

Individualised consideration refers to the leader's ability to distinguish followers and coach them according to their individual needs. The leader can make the best use of this individualised consideration by providing "socio- emotional support" (Harms \& Crede, 2010, p. 6) which involves mentoring followers, encouraging followers to self-actualise, and empowering them. Thus, all these dimensions of TL are inherently related to the leader's emotional and interpersonal effectiveness in driving the followers to reach their desired goals (team or individual) by going beyond expectation.

\section{What is Emotional Intelligence?}

One common feature of human being is that everyone is more or less driven by feelings and emotions. Leaders, being humans, are not exception to this. Emotions, thus, begins to play a vital role in managing people. Hence, emotions lie in the core of emotional intelligence. It was, indeed, Daniel Goleman (1995) who first brought the term EI to a wide range of audience with his bestselling book, Emotional Intelligence: Why IT Can Matter More Than IQ. Goleman (1995) emphasises EI as "the sine qua non of leadership" and defines EI in a meaningful way. According to him, EI is that ability of us which can recognise our own feelings as well as those of others in order to motivate ourselves, and to manage emotions intelligently in both ourselves and our relationships (Goleman, 2000). This reveals the multifaceted nature of emotional intelligence built on five components: self-awareness, self-regulation, motivation, empathy, \& social skill (Goleman, 1995). While the first three components of EI are self-management skills, the last two are the parts of management relationship of leaders with others (Goleman, 1995).

\section{EI competencies and Transformational Leaders}

Self-awareness refers to individual's profound perception about positive and negative side of one's own emotions and desires. According to Goleman (1995), self-awareness means having a deep understanding of one's emotion, strength, weakness, needs, and drives and having a clear knowledge of his or her own values, goals, and dreams (Goleman et al., 2002). Self-aware leaders are likely to be confident as they trust on their intuition and they do neither let their feeling rule over them, nor even let their emotion get out of control. They know their strength and weakness very well and work according to that so that they can perform well. Furthermore, they allow the followers to take risk, encourage them to think and act individually and be a part of the success. As a result, building a strong emotional bond of trust and commitment with the followers the leader acquires charisma. And charisma is a major contributor to a transformational leader's idealised influence (Pinos, et al., 2006), a core dimension of transformational leadership, which suggest that self-awareness is positively related to the idealised influence dimension of transformational leadership behaviour.

Self regulation is the ability to keep destructive feelings and impulses under control. Goleman (2004) identifies this competency as an ongoing inner conversation that control negative feelings and emotions. A self managed leader control emotions rather than being controlled by it (Goleman et al., 2002).It enables leaders to think reasonably and also reshape their emotion effectively. This EI competency facilitates a leader to change the status quo and also to build an environment of trust and fairness, a fundamental requirement of transformational leader.

For a transformational leader motivation, another component of EI is important. Goleman (1995) defines motivation as a deeply embedded desire to achieve for the sake of achievement. A self-motivated leader brings about ideas, has passion for work, and has inquisitive urgency for optimistic view and creative challenges. Being highly motivated the leader remains truly committed to organisational goal. Therefore, optimism and organisational commitment are fundamental to strong leadership (Goleman, 2004). Transformational leaders, being internally motivated and highly committed, can help the followers develop 'a sense of purpose' (pinos et al., 2006, p. 68) in the organisation's mission. Emphasising on this particular EI competency Sosik\& Megerian (1999 cited in Barbuto\& Burbach, 2006, p. 55) support the emotional underpinnings of TL. They consider motivation, more specifically internal motivation, a strong prerequisite for effective TL and point out that transformational leaders are actively engaged within their organisation and they believe that they can influence their environment. More precisely, being self-motivated the transformational leaders can even generate a shared vision and motivation to followers. And this reinforces that intrinsic motivation is deeply linked with TL behaviour.

Empathy is regarded as the fundamental competence of social awareness (Goleman et al., 2002, p. 50). It means giving a thoughtful consideration of others' feeling and making intelligent decisions showing respect to others feelings (Goleman, 2004). A core component of TL is the ability to empathise with followers. Leaders can show greater empathy towards followers originated from diverse culture. Empathetic leaders can sense the needs of others and respond accordingly. 
An individual's ability to manage relationship with others is called social skill (Goleman, 1995). Social skill allows leaders to transfer their EI to work, to build a positive bond with followers, and inspire them with a compelling vision and a common mission (Goleman et al., 2002). Thereby, socially skilled leaders can act as catalyst to inspire followers to be innovative, challenging and passionate. With their behaviour the leaders can inspire the followers to attain positive response, as positive behaviour results in positive response. In fact, the leaders' empathetic response as well as socio emotional support to their followers is a key to their ability not only to acquire inspirational motivation, but also to change the organisational behaviours and effectiveness. The leaders with such social skills inspire greater depth of self-exploration in followers (Long \& Schultz, 1973 cited in Barbuto \& Burbach, 2006, p. 53). Based on the above arguments it can be proposed that social skill is positively related to two major dimensions of transformational leadership, namely inspirational motivation and intellectual stimulation.

\section{Correlation between emotional intelligence and transformational leadership}

An appropriate emotional display and recognition of others' emotional displays are essential for successful leadership (Bohem, 1999 cited in Harms \& Crede, 2010). A number of theoretical arguments can be considered to analyse the relationship between EI and effective leadership, specifically TL. The reason why the leaders high in emotional intelligence adhere to transformational behaviours is implicit. First, the leaders' selfcontrol and self-management ability is very much consistent with the essence of idealised influence (Barling, et al., 2000). Self-awareness facilitates transformational leadership enabling the leaders to go beyond average sense of purpose and meaning (Sosik \& Megarian, 1999 cited in Harms \& Crede, 2010, p.7). More precisely, when leaders can understand both their own emotions and others', they know well how to be emotionally close and supportive to the followers, enhance their level of trust, motivation, and commitment, and act as a role model to them.

Second, leaders with high emotional intelligence would be ideally placed to realise the extent to which followers' expectations could be raised, a hallmark of inspirational motivation (Barling, et al., 2000). Similarly, carrying a research George (2000 cited in Harms \&Crede, 2010, p. 7) argues that transformational leaders can use emotional appeals to acquire inspirational motivation. Indeed, the accurate recognition of the emotions of others is critical to a leader's capability to inspire and build relationships (Carney \& Harrigan, 2003 cited in Wang \& Huang, 2009, p. 382). Thus, emotionally intelligent leaders can exercise the TL of utilising followers' emotion for inspirational motivation.

Third, the leaders' ability to understand followers' needs and interact accordingly is a part of individualised consideration. For instance, being skilled at emotional management the leaders are equally skilled to give up their own personal needs and prioritise the needs of others (Soski \& Megarian, 1999 cited in Harms \& Crede, 2010, p. 6). Thereby, with its emphasis on the ability to manage relationships positively, leaders manifesting emotional intelligence would be likely to manifest individualised consideration (Barling, et al., 2000). It points out that in order to be transformational leader empathy is essentially important and this competency of EI would enable leaders to show individual consideration towards followers. Besides this interrelation between different aspects of EI and transformational leadership, some other researchers point out that that adherence to professional or moral standards of behaviour are the basic and common aspects of both EI and transformational leadership (Brown et al., 2006 cited in Harms \& Crede, 2010, p. 7).

\section{Conclusion}

Thus, transformational leadership is positively related to emotional intelligence. In other words, transformational leadership and emotional intelligence go together. More precisely, a transformational leader has to have emotional intelligence in order to reap individual as well as organisational success. By developing the five components of emotional intelligence, a leader will be able to develop his sense of identity, commitment, and control over emotions. There are some limitations of the study that need to be addressed. The relationship between the emotional intelligence of leaders and their practice in transformational leadership requires a wide range of primary research. Many literature have given efforts to establish a relationship between EI and TL, however, no single study can claim to be successful to show an apparent relationship. This introductory essay could be a source of further extension through blending primary data on the relationship between emotional intelligence transformational leadership.

\section{Reference}

[1]. Abraham, R., 2000. The role of job control as a moderator of emotional dissonance and emotional intelligence outcome relation ships. The Journal of Psychology, 134, 169-84.

[2]. Miller, M (1999) Emotional intelligence helps managers succeed. Credit Union Magazine, 56 (7), 25-26.

[3]. Goleman, D., 1998. What makes a leader? Harvard Business Review, 76, 93-104

[4]. Watkin, C., 2000. Developing emotional intelligence. International Journal of Selection and Assessment, 8, 89-92.

[5]. George, J. M. (2000). Emotions and leadership: The role of emotional intelligence. Human Relations, 53(8), $1027-1055$. 
[6]. Bass, B.M., 1998. Transformational Leadership: industrial, military, and educational impact.

[7]. NJ: Lawrence Erlbaum Associates.

[8]. Harms, P.D. \& Crede, M. 2010. Emotional intelligence and transformational and transactional leadership: a meta-analysis. Journal of Leadership \& Organisational Studies, 17(1), 5-17.

[9]. Kupers, W. \&Weibler, J., 2006. How emotional is transformational leadership really: some suggestions for a necessary extension. Leadership \& Organisation Development Journal, 27(5), 368-383.

[10]. Northouse, P.G., 2007. Leadership: theory and practice. New Delhi: Sage Publications India Pvt. Ltd.

[11]. Wang, Y. \& Huang, T., 2009.The relationship of transformational leadership with group cohesiveness and emotional intelligence. Social Behaviour And Personality, 37(3), 379-392.

[12]. Goleman, D., 1995. Emotional Intelligence: why IT can matter more than IQ. New York: Bantam Books.

[13]. Goleman, D., 2000. Working with Emotional Intelligence. New York: Bantam Books.

[14]. Goleman, D. Boyatzis, R. \& McKee, A., 2002.Primal leadership. Massachusetts: Harvard Business School Publishing.x3

[15]. Pinos, V. Twigg, N., Parayitam, S., Olson, B. (2006). Leadership in the 21st century: The effect of emotional intelligence. Academy of Strategic Management Journal, 5, 61-74.

[16]. Barbuto, J.E. \& Burbach, M.E. (2006). The emotional intelligence of transformational leaders: a field study of elected officials. Journal of Social Psychology, 146(1), 51-64.

[17]. Barling, J., Slater, F., Kelloway, E. K. (2000). Transformational leadership and emotional intelligence: an exploratory study. Leadership and Organization Development Journal, 21, 157-161. 